\title{
Legal Standing of the Conveyancer Column on the SSPD BPHTB Form in Lombok Island
}

\author{
Lalu Denu Aktapragia ; Salim; Kaharudin ${ }^{2}$ \\ ${ }^{1}$ Graduate Program Student in Notary, Faculty of Law, Mataram University, Indonesia \\ ${ }^{2}$ Faculty of Law, Mataram University, Indonesia \\ http://dx.doi.org/10.18415/ijmmu.v6i3.747
}

\begin{abstract}
This study aims to determine the legal essence of the inclusion of the conveyancer signature and identity columns on the SSPD BPHTB form in Lombok Island, determine the legal basis of the policy of the inclusion of the conveyancer signature and identity columns on the SSPD BPHTB form in Lombok Island and determine the legal consequences of inclusion of conveyancer signature and identity columns on SSPD BPHTB form in Lombok Island. This is empirical legal research that uses a sociological juridical approach, statute approach, conceptual approach and comparative approach. The results showed that 1) the legal essence of the inclusion of the conveyancer signature and identity columns on the SSPD BPHTB form is: a) based on legal certainty, i.e. providing certainty to find out the conveyancer location and identity that takes care of the transfer of land rights and providing certainty for the regional government for profit sharing from central and regional tax revenues, b) based on benefit, i.e. it can provide benefits to the Regional Revenue Agency, but it adversely affects conveyancer, c) based on justice, i.e. it does not reflect the principle of justice. 2) The legal basis of the inclusion of the conveyancer signature and identity columns on the SSPD BPHTB form can be found in the legislation. 3) Policies of the inclusion of the conveyancer signature and identity columns on the SSPD BPHTB form give legal consequences to the conveyancer which creates liability and sanction.
\end{abstract}

Keywords: Legal Standing; Conveyancer Column; SSPD BPHTB Form

\section{Introduction}

According to laws and regulations, every implementation of the transfer of rights to land will be taxed. Taxes which are the result of legal actions of the transfer of rights to land and buildings are Income Tax and Customs for Land and Building Rights (BPHTB). Mustofa (2014) explained that in every transfer of rights to land or Property Rights to the Flats, there are 2 (two) types of taxes to be paid, that include (1) Income Tax that must be paid on behalf of the party transferring land rights or Property Rights to the Flats, which are regulated in Government Regulation No. 48 of 1994 concerning Payment of Income Tax on income from the transfer of rights to land and or buildings, amended with Government Regulation No. 27 of 1996, amended again by Government Regulation No. 79 of 1999, finally amended by Government Regulation No. 71 of 2008. (2) Customs for Land and Building Rights (BPHTB) that 
must be paid on behalf of recipients/ who obtain rights to land or Property Rights to the Flats, which are regulated in Law No. 28 of 2009, i.e. the Law on Regional Taxes and Regional Levies. In addition, matters relating to BPHTB are specifically regulated in Article 85 to Article 93. This law shall come into force as from January 1, 2010.

The collection of BPHTB, since the enactment of Law No. 28 of 2009 concerning Regional Taxes and Regional Levies (Law No. 28 of 2009), has become the authority of each Regency/ City Government (Bawazier, 2018). The collection authority covers all matters related to BPHTB collection activities, which the determination of the policy is carried out by each Regency/ City Regional Government. Regarding to this law, the presence or absence of the conveyancer signature and identity columns on the SSPD BPHTB form is the authority of each Regency/ City Regional Government to determine it.

Regency/ City Governments in the Lombok Island have established Regional Regulations on Customs for Land and Building Rights. For example, West Lombok Regional Regulation No. 1 of 2011 and Central Lombok Regency Regulation No. 14 of 2010 stipulate the procedure for collecting BPHTB. Based on the provisions in the regional regulation, the taxpayer is obliged to pay his/her own tax by completing the Regional Tax Payment Letter, Customs for Land and Building Rights (SSPD BPHTB) form clearly, correctly and completely. This BPHTB payment is referred to as the self-assessment system in which the taxpayer is given the trust to calculate and pay the tax payable by using a BPHTB Deposit Letter and reporting it without basing the issuance of a tax assessment letter. ${ }^{1}$

Based on preliminary observation in West Lombok Regency in the process of buying and selling land and buildings for which the deed is made before the conveyancer, researcher found that in West Lombok Regency there is a conveyancer involvement in BPHTB payments contained in the SSPD BPHTB form issued by the Regency Revenue Service/ City. Within the form, there is a conveyancer signature and identity columns filled in by the conveyancer after the taxpayer fills in the SSPD BPHTB form correctly, clearly and completely. Meanwhile, in Central Lombok Regency, researcher did not find the conveyancer signature and identity columns on the SSPD BPHTB form.

The preliminary information, which researcher obtained from notary/ conveyancer partners in West Lombok and Central Lombok Regencies, showed that BPHTB payments in Central Lombok did not require a conveyancer signature and identity because the SSPD BPHTB form did not include the conveyancer signature and identity columns. Meanwhile, in West Lombok Regency, BPHTB payments must use conveyancer signature and stamp. As a result, there is often a return of the form or SSPD BPHTB form by the Regional Revenue Agency in West Lombok Regency because its conveyancer signature and identity columns are not signed and stamped.

To include and not to include the conveyancer signature and identity columns on the SSPD BPHTB form is the policy of each Regency/ City Government. The inclusion of the conveyancer column on the SSPD BPHTB form certainly has legal consequences that would endanger the legal standing of conveyancer as a public official who has worked honestly and professionally; if one day there is a taxpayer who tries to avoid tax avoidance by not honestly listing the value or price of transactions in the SSPD BPHTB form. The transaction value stated in the SSPD BPHTB form will be used as the Tax Object Acquisition Value (NPOP: term for BPHTB). If there is tax avoidance in the implementation of the tax payment, it will certainly be detrimental to the conveyancer as the party who is considered to know the first time about the act.

\footnotetext{
${ }^{1}$ Indonesia, Law No. 20 of 2000 concerning Amendments to Law No. 21 of 1977 concerning the Fees for Acquisition of Land and Building Rights, State Gazette of 2000 No. 130, Supplement to State Gazette No. 3988, see explanation of Article 10 paragraph (1).
} 
On the other hand, the inclusion of conveyancer signature and identity columns does not have a clear legal basis. Article 15 paragraph (3) West Lombok Regional Regulation No. 1 of 2011 states that "further provisions regarding the form, content, size of procedures for payment and delivery of SSPD as well as SSPD studies as referred to in Article 14 paragraph (2) and paragraph (4) shall be stipulated by Regent Regulations". However, to this day, there is no West Lombok Regent Regulation that regulates the procedures for filling and delivering SSPD BPHTB. Thus, the inclusion of conveyancer signature and identity columns on the SSPD BPHTB form issued by the West Lombok Regency Revenue Agency raises legal problems.

Thus, the researcher found a vacuum of norms in the inclusion of the conveyancer signature column and the conveyor office legality stamp on the SSPD BPHTB form which resulted in the emergence of legal problems for the conveyancer for the correctness of the contents of the form.

This is an empirical legal research that applies sociological juridical approach, statute approach, conceptual approach and comparative approach (Marzuki, 2017). The method and technique for collecting legal materials were carried out through interviews; i.e. by giving questions that have been designed in advance to get answers related to research. The targets of the interview in this research are the Conveyancer, the Head of the West Lombok Regency and Central Lombok Regency Revenue Agency, and the academics.

\section{Discussion}

Legal Essence of the Inclusion of the Conveyancer Signature and Identity Columns on the SSPD BPHTB Form in Lombok Island

The existence of fiscal decentralization allows each region to determine the sources of revenue according to their potential. Regional authority in fiscal matters is realized by collecting one of the potential regional revenues from regional taxes as stipulated in Law 28 of 2009 (Ismail, 2005). The Law mandates that one type of regency/ city tax is BPHTB Tax (Customs for Land and Building Rights), which uses NPOP (Tax Object Acquisition Value) as the basis for imposing the tax.

BPHTB is a tax whose implementation utilizes a self-assessment system. In this process, conveyancer has a significant role in BPHTB collection because conveyancer is a general official associated with land sale and purchase transactions. Conveyancer will sign an authentic deed after the BPHTB tax is paid in full by the taxpayer. Conveyancer can only sign the deed of transfer of rights to land and/or buildings after the taxpayer submits the proof of tax payment. This is confirmed in Article 91 paragraph (1) of Law No. 28 of 2009 which states that "conveyancer/ notary can only sign deeds of transfer of rights to land and/ or buildings after the taxpayer submits the proof of tax payment". If this is violated, the conveyancer will accept the consequences of the violation as specified in the same Law in Article 91 paragraph (1) which states that "conveyancer/ notary and head of office, who are in charge of state auction services and violate the provisions as referred to in Article 91 paragraph (1) and paragraph (2), will be imposed by administrative sanctions in the form of a fine of IDR 7,500,000 (seven million and five hundred thousand rupiah) for each violation".

The impact of the authority transfer in the BPHTB collection from the Central Government to the Regency/ City Regional Government gives authority to each Regency/ City Government to determine policies for all matters relating to BPHTB collection. The policy of BPHTB collection on Lombok Island is very dependent on the policy concepts of each region; thus, the policies of each regency/ city are not homogeneous such as the BPHTB collection policy in West Lombok Regency and Central Lombok Regency. 
The policy of BPHTB collection in West Lombok Regency is based on Regional Regulation No. 1 of 2011 concerning BPHTB, while BPHTB collection in Central Lombok Regency is based on Regional Regulation No. 14 of 2010 concerning Regional Taxes. The Regional Regulation regulates the procedure for BPHTB collection with the concepts of each region. It means that the procedure for BPHTB collection in West Lombok Regency is different from the procedure for BPHTB collection in Central Lombok Regency. One noticeable difference is the inclusion of the conveyancer signature and identity columns on the SSPD BPHTB form. West Lombok includes conveyancer signature and identity columns on the SSPD BPHTB form, while Central Lombok does not. To include and not to include the conveyancer signature and identity columns on the SSPD BPHTB form is a form of policy from each Regional Government. However, it needs to be tested whether or not the policy contains the essence of a policy or law.

According to the Indonesian Dictionary, essence is a fundamental, core, or the most basic thing. ${ }^{2}$ In the theory of law, the essence of law includes certainty, benefit and justice. The following is a policy analysis to include and not to include the conveyancer signature and identity columns on the SSPD BPHTB form based on the essence of the policy.

The first essence is legal certainty which is one of the legal objectives in order to realize justice. Thus, the concrete form of legal certainty is the implementation or enforcement of the law against an act regardless of the object who conducts the act. According to Marzuki (2008), legal certainty is a concrete form of rule of law in written and unwritten forms that contain general rules that guide everyone to behave in society. Thus, legal certainty will direct the community to act in an orderly manner.

Based on interview that the researcher did with Mr. Wira Kurniawan ${ }^{3}$, he mentioned that the West Lombok Regency Government's policy in the inclusion of the conveyancer signature and identity columns on the SSPD BPHTB form aims to provide legal certainty for the government to find out the conveyancer location and identity that took care of the transfer of land rights. In the management of the transfer of land rights, the taxpayer cannot take care of his/her own requirements but it must be carried out through a conveyancer. Therefore, the office address and identity of the conveyancer must be known by the West Lombok Regency Government. Although the conveyancer work area, as mentioned in Government Regulation No. 24 of 2016 jo. Government Regulation No. 37 of 1998, is a provincial area, if the conveyancer office address and identity are outside the West Lombok Regency area, then the government revenue data becomes uncontrolled. Thus, the inclusion of the conveyancer signature and identity columns also provides data certainty for the West Lombok Regency Government for the profit sharing from central and regional tax revenues.

Inclusion of the conveyancer signature and identity columns on the SSPD BPHTB form has been going on for a long time even before the promulgation of West Lombok Regional Regulation No. 1 of 2011, the inclusion of the column has been enacted. ${ }^{4}$ However, the inclusion of this column received a response from several conveyancer officials having their office address in the West Lombok Regency who stated that if the inclusion of the conveyancer signature and identity columns on the SSPD BPHTB form is intended to provide legal certainty of the conveyancer location and identity whose office in West Lombok, it does not have to be included in the SSPD BPHTB form. The use of a conveyancer stamp is sufficient to show that the conveyancer official concerned is a conveyancer working in the area of West Lombok Regency; even without having to sign the form. The essence of the SSPD BPHTB form is to calculate the tax debt value for the transfer of land rights carried out by the taxpayer. The liability of the

\footnotetext{
${ }^{2}$ Indonesia Dictionary, https://kbbi.kemdikbud.go.id/entri/esensi, accessed on March 15, 2019.

${ }^{3}$ The result of interview with Wira Kurniawan, the Head of Land and Building Tax and BPHTB, Financial Revenue Agency of West Lombok Regency, February 11, 2019.

${ }^{4}$ The result of interview with Wira Kurniawan, the Head of Land and Building Tax and BPHTB, Financial Revenue Agency of West Lombok Regency, February 11, 2019.
} 
SSPD BPHTB form is on the taxpayer; thus, involving a conveyancer in the SSPD BPHTB form is a mistake that may create legal consequences to the conveyancer official for the correctness of the SSPD BPHTB form. ${ }^{5}$

On the other hand, the absence of the conveyancer signature and identity columns on the SSPD BPHTB form in Central Lombok is caused by the format of the form that does not contain a conveyancer column from the finance ministry and the tax directorate. That format of the SSPD BPHTB form has long been used and has never changed until today. ${ }^{6}$ The exclusion of the conveyancer signature and identity columns is also a form of the self-assessment system in BPHTB payment, in which the taxpayer him/herself fills in, calculates the tax amount, and makes payment of the tax. To provide certainty about the correctness of the data and fill in the form, before completing the SSPD BPHTB form, verification of the tax object is carried out first then the amount of tax payable is agreed upon by the verification team formed by the Central Lombok Regional Revenue Agency. The legal standing of conveyancer in this case is only as a companion to the taxpayer to fulfill the requirements for the transfer of rights to land and buildings. In addition, the determination of whether the conveyancer has an office in the Central Lombok Regency is known through a conveyancer stamp on the requirement documents for the transfer of rights to land and buildings.

However, the BPHTB payment process in Central Lombok is carried out by verification for the land sale and purchase. After verification is carried out, the tax authorities (Regional Revenue Agency Team) will issue a letter on the amount of tax payable that must be paid by the taxpayer, then the taxpayer will fill the SSPD BPHTB form. Under these conditions, the BPHTB payment system that is supposed to use the self-assessment system changes to the official-assessment system. ${ }^{8}$ This, according to the researcher, obscures the concept of the full self-assessment system in BPHTB payment.

The second essence is the benefit in which the community expects benefits in the implementation and enforcement of law and/ or policy. The law is intended for humans. So, the implementation of law or law enforcement must provide benefits or uses for the community. It is not appropriate if the law implemented or enforced instead creates anxiety in the community itself (Mertokusumo, 2010). Good law is if the application of legal norms provides good benefits for the community and creates prosperity for other communities. Jeremi Bentham ${ }^{9}$ stated that the purpose of the law is to ensure the greatest happiness for as many people as possible (the greatest good of the greatest number). So, the purpose of the law must produce the greatest pleasure or happiness for the largest number of people.

The policy of inclusion the conveyancer signature and identity columns on the SSPD BPHTB form can provide benefits for the West Lombok Regional Revenue Agency, but it has a negative impact on the conveyancer. West Lombok Regional Revenue Agency uses the conveyancer signature and identity columns to find out the working area of the conveyancer and synchronize Regional Revenue

\footnotetext{
5 Interview with (1) Samsaimun, notary/ conveyancer official, Jalan Selaparang Gerung Selatan, February 15, 2019, (2) Lalu Mulyadi, notary/ conveyancer official, Jalan TGH Ibrahim Khalidy, Bengkel, February 13, 2019, (3) Nining Herlina, notary/ conveyancer official, Jalan HL Anggrat No. 10 North Gerung, February 15, 2019, (4) Nani Suryani, notary/ conveyancer official, Jalan TGH Saleh Hambali, Bengkel, February 13, 2019, (5) Muhammad Shaleh Hambali, notary/ conveyancer official, Jalan Raya Senggigi No. 27 Meninting Batulayar, February 19, 2019.

${ }^{6}$ Interview with Lalu Jayaprana, the Head of Land and Building Tax and BPHTB, Financial Revenue Agency of Central Lombok Regency, February 12, 2019.

${ }^{7}$ Interview with Lalu Jayaprana, the Head of Land and Building Tax and BPHTB, Financial Revenue Agency of Central Lombok Regency, February 12, 2019.

${ }^{8}$ Interview with (1) Saharjo, notary/ conveyancer official, Jalan Anyelir No. 36 Prapen Praya, February 12, 2019, (2) Lalu Abdurrahman, notary/ conveyancer official, Jalan S Parman No. 4 Praya, February 17, 2019, (3) Halim Nata Atmadja, notary/ conveyancer official, Jalan Jendral Sudirman No. 88a, Leneng Praya, February 17, 2019. 9 -
} 
Agency data with the conveyancer per-period. ${ }^{10}$ Meanwhile, for conveyancers, the inclusion of conveyancer signature and identity columns can be detrimental if one day a mistake or legal violation of the NJOP is included in it or it is only used as a formality that can be replaced through another alternative. The inclusion policy on the conveyancer signature and identity column should provide benefits to the conveyancer and taxpayers, not just the Regional Revenue Agency. ${ }^{11}$ As what Prof. Sudikno said that a policy made by the Government/ Regional Government, in this case the inclusion of a conveyancer signature and identity columns, must provide the maximum benefits to the conveyancer and the community.

Meanwhile, the policy of not including the conveyancer signature and identity columns in Central Lombok does not have a direct consequence. However, BPHTB payment system used in Central Lombok provides benefits to activate the role of taxpayers to calculate, examine and pay the value of their tax debt themselves. However, the influence or benefits of not including the conveyancer signature and identity columns on the SSPD BPHTB form cannot be removed because it is part of the system used by the Central Lombok Regional Revenue Agency.

The third essence is justice which is one of the most discussed purposes of law throughout the course of the history of legal philosophy. Justice is the most important and the only legal goal (Shidarta, 2006). The inclusion of conveyancer signature and identity columns on the SSPD BPHTB form, if it is analyzed based on the principle of justice, is found to have not reflected the principle of justice, because this policy does not include conveyancer or notary/ conveyancer organization in its discussion. ${ }^{12}$ On the other hand, filling in the SSPD BPHTB form is a liability or a taxpayer's obligation; so, the inclusion of the conveyancer signature and identity columns is a policy outside the obligation of the taxpayer. So, all the contents of the SSPD BPHTB form are not the obligation and liability of a conveyancer. ${ }^{13}$ In this case, justice is all things relating to attitudes and actions in human relations and contains a demand that people treat each other according to their rights and obligations (Shidarta, 2006). The SSPD BPHTB form is basically intended for taxpayers to calculate BPHTB values and as proof of BPHTB payment. So,

${ }^{10}$ Interview with Wira Kurniawan, the Head of Land and Building Tax and BPHTB, Financial Revenue Agency of West Lombok Regency, February 11, 2019.

${ }^{11}$ Interview with (1) Eti Susanti, Jalan Raya Senggigi Km 4 Senteluk Batulayar, February 18, 2019, (2) Saipul Rahman, Jalan Raya Senggigi Meninting Batulayar, February 18, 2019, (3) Abdul Khalid P, Jalan Pariwisata Bale Pelangi Sandik Batulayar Housing, February 18, 2019, (4) I Made Budi Priyatnadi, jalan TGH Lopan No. 19 Labu Api, February 19, 2019.

${ }^{12}$ Interview with (1) Samsaimun, notary/ conveyancer official, Jalan Selaparang South Gerung, February 15, 2019, (2) Lalu Mulyadi, notary/ conveyancer official, Jalan TGH Ibrahim Khalidy, Bengkel, February 13, 2019, (3) Nining Herlina, notary/ conveyancer official, Jalan HL Anggrat No. 10 North Gerung, February 15, 2019, (4) Nani Suryani, notary/ conveyancer official, Jalan TGH Saleh Hambali, Bengkel, February 13, 2019, (5) Muhammad Shaleh Hambali, notary/ conveyancer official, Jalan Raya Senggigi No. 27 Meninting Batulayar, February 19, 2019.

${ }^{13}$ Interview with (1) Samsaimun, notary/ conveyancer official, Jalan Selaparang South Gerung, February 15, 2019, (2) Lalu Mulyadi, notary/ conveyancer official, Jalan TGH Ibrahim Khalidy, Bengkel, February 13, 2019, (3) Nining Herlina, notary/ conveyancer official, Jalan HL Anggrat No. 10 North Gerung, February 15, 2019, (4) Nani Suryani, notary/ conveyancer official, Jalan TGH Saleh Hambali, Bengkel, February 13, 2019, (5) Muhammad Shaleh Hambali, notary/ conveyancer official, Jalan Raya Senggigi No. 27 Meninting Batulayar, February 19, 2019, (6) Eti Susanti, notary/ conveyancer official, Jalan Raya Senggigi Km 4 Senteluk Batulayar, February 18, 2019, (7) Saipul Rahman, notary/ conveyancer official, Jalan Raya Senggigi Meninting Batulayar, February 18, 2019, (8) Abdul Khalid P, notary/ conveyancer official, Jalan Pariwisata Bale Pelangi Sandik Batulayar Housing, 18 februari 2019 , (9) I made budi priyatnadi, Pejabat Notaris/ conveyancer, Jalan TGH Lopan No. 19 Labu Api, February 19, 2019, (10) Dwiratna Kurniasari, notary/ conveyancer official, Jalan Pariwisata Gunung Sari, February 19, 2019, (11) Sayaman Harahap, notary/ conveyancer official, Jalan Pariwisata Batu Layar, February 22, 2019, (12) Haerun Inayah, conveyancer official, Jalan Raya Jatisela No. 1 Sesela Gunung Sari, February 22, 2019, (13) Djuju Hendro, conveyancer official, Gerung, February 22, 2019 (14) Fitri Susanti, notary/ conveyancer official, Jalan Soekarno Hatta Gerung, February 22, 2019. 
everything related to the form becomes a liability and obligation of the taxpayer. Thus, putting other obligations in the form is a mistake or injustice. For example, it is unfair to require the conveyancer to sign and stamp the conveyancer signature and identity columns on the form, which the truth and legality of the form become void if it is not signed and stamped.

Legal Basis related to the Policy of the Inclusion of the Conveyancer Signature and Identity Columns on SSPD BPHTB Form in Lombok Island

The legal basis is a provision in the legislation that becomes the basis or core for any legal implementation or action by legal subjects; individuals and legal entities. In addition, the legal basis can also be in the form of legal norms or provisions in legislation that form the basis or core for the formation of newer laws and/ or lower ranks in the hierarchy or order of laws and regulations.

The legal basis, in the establishment of a policy for the inclusion of the conveyancer signature and identity columns on the SSPD BPHTB form, is found in the laws and regulations. Law No. 28 of 2009 has given authority to the regional government to collect BPHTB. Then, it is confirmed through a circular letter from the director general of tax No. PEM-01/PJ.09/2010 concerning the Management Transfer of BPHTB. The authority covers all matters relating to the BPHTB collection. In this case, the policy includes the conveyancer signature and identity columns on the SSPD BPHTB form.

The circular letter instructs each regency/ city to make regional regulations regarding BPHTB; thus, the Regional Regulation becomes the basis for each regional government to adopt the policy of BPHTB collection. Based on these provisions, the West Lombok Regency Government has established Regional Regulation No. 1 of 2011 concerning BPHTB as a legal basis for taking policy in BPHTB collection in West Lombok Regency. Regarding payment and billing procedures, Article 14 and Article 15 Regional Regulation No. 1 of 2011 states that BPHTB payment is made by taxpayer using the SSPD and further provisions regarding the form, content, size, procedure for payment and delivery of SSPD are stipulated by Regent Regulation. However, the provisions concerning the form, content, size, procedure for payment and delivery of SSPD have not been regulated through the regulations of the West Lombok Regent. Thus, in this case, there is a legal vacuum in the inclusion of the conveyancer signature and identity columns on the SSPD BPHTB form.

Based on the attachment, ${ }^{14}$ The Director General of Taxes Decree Number Kep-269/PJ/2001, concerning the Guidelines for Implementing BPHTB Payment and Form as well as Functions of BPHTB Deposit Letter, states that the form and content of the BPHTB Deposit Letter form (which is now known as SSPD BPHTB) do not include specific column for conveyancer signature and identity. Thus, the inclusion of conveyancer signature and identity columns on the SSPD BPHTB form is a policy initiative carried out by the West Lombok Regency Regional Revenue Agency for BPHTB collection.

Meanwhile, in Central Lombok has long used the format of SSPD BPHTB form which does not include a special column for the conveyancer signature and identity and the format of the form is received through an attachment to the tax office or tax directorate. Even though the head of the Central Lombok Regional Revenue Agency could not show the letter or attachment, it is assumed that it is the attachment of the Director General of Taxes Decree No. Kep-269/PJ/2001, because the attachment is similar to the SSPD BPHTB format of Central Lombok. Thus, the legal basis of the SSPD BPHTB format used is the Director General of Tax Decree No. Kep-269/PJ/2001.

\footnotetext{
${ }^{14}$ Tax Regulations, Attachment to Deposit Letter of BPHTB, see https://pajaksite.files.wordpress.com/2018/02/kep269-pj-2001.pdf, accessed on April 2, 2019. Interview with Wira Kurniawan, the Head of Land and Building Tax and BPHTB, Financial Revenue Agency of West Lombok Regency, February 11, 2019.
} 
Provisions on the format and content of the SSPD BPHTB form are also regulated in Article 82 paragraph (5) of Central Lombok Regional Regulation No. 14 of 2010 which states that the format and content of the SSPD are regulated further by a Regent Regulation. However, the Regent Regulation governing the format and content of the SSPD BPHTB is not established or nonexistent. Thus, provisions regarding the SSPD BPHTB format have a norm of emptiness.

Referring to the hierarchy or order of laws and regulations, based on Law No. 12 of 2011 concerning the Establishment of Legislation Regulations, article 7 (1) states that the type and hierarchy of legislation consist of:

a. The 1945 Constitution of the Republic of Indonesia;

b. Decree of the People's Consultative Assembly;

c. Law/ Government Regulation Substitution to Law;

d. Government Regulation;

e. Presidential Decree;

f. Provincial Regulation; and

g. Regency/ City Regulation.

Then, Article 8 (1) states that the types of legislation other than those referred to in Article 7 paragraph (1) of Law No. 12 of 2011 above, include regulations stipulated by the People's Consultative Assembly, House of Representatives, Regional Representative Council, Supreme Court, Constitutional Court,Audit Board,Judicial Commission,Bank Indonesia, Ministers, agencies, institutions or commissions established by the Law or Government at the behest of the Law, Provincial Regional Representatives, Governors, Regency / City People Representatives, Regent / Mayor, Village Head or equivalent.

Based on the hierarchy above, the legal standing of the Regional Regulation is higher than the Director General of Tax Decree with its own legal standing under the Ministry of Finance. Then, a better legal basis for use in BPHTB collection or inclusion of the conveyancer signature and identity column on the SSPD BPHTB form is to use regional regulation or Regulation of the Regent/ Mayor.

Legal Consequences of Inclusion of Conveyancer Signature and Identity Columns on the SSPD BPHTB Form in Lombok Island

Legal consequences are a result caused by the law against an act committed by a legal subject. Legal consequences give rise to a result of actions to obtain an expected outcome by legal actors. The consequence, in this case, is the result of being regulated by law, while action is a legal action that is in accordance with applicable law (Soeroso, 2009).

Legal consequences are the consequences of a legal event, which can be as follows:

1. The emergence, change or disappearance of a legal situation. For example, legal consequences can change from being not legal to being legal when someone is 21 years old.

2. The emergence, change or disappearance of a legal relationship between two or more legal subjects, where the rights and obligations of one party face the rights and obligations of the other party. For example, $\mathrm{X}$ entered into a house lease agreement with $\mathrm{Y}$, so the legal relationship emerges between $\mathrm{X}$ and $\mathrm{Y}$ if the rent for the house ended which is marked by the fulfillment of all the lease agreements and then the legal relationship disappeared.

3. The emergence of sanctions when taking actions against the law. For example, a thief who is penalized is a legal consequence for the thief's actions; i.e. taking other people's goods without rights and illegally. 
Based on the above provisions, the policy for the inclusion of the conveyancer signature and identity columns on the SSPD BPHTB form certainly creates legal consequences for the conveyancer. Legal consequences of the inclusion of the conveyancer signature and identity columns on the SSPD BPHTB form include as follows:

\section{Creating liability}

The conveyancer signature and identity columns contained on the SSPD BPHTB form have the information "the undersigned" in the column. The information of the undersigned indicates that the conveyancer knows the truth, clarity and completeness of the contents of the form. It means that the conveyancer is liable to the truth, clarity, and completeness of the contents of the form; hence, conveyancer may be subject to sanctions if the act is in conflict with the law.

\section{Creating sanction}

If the taxpayer commits tax evasion by filling in incorrectly or attaching false information in the SSPD BPHTB form so that it is detrimental to regional finance, the conveyancer as an official deemed to know the situation will be liable to administrative sanctions or even criminal sanctions.

Criminal Provisions of Regional Regulation No. 1 of 2011 and Regional Regulation No. 14 of 2010 state that taxpayers who fill incorrectly or incompletely and/ or attach incorrect information that is detrimental to regional finance may be subject to criminal and administrative sanctions. This provision is indeed directed to taxpayers; however, the undersigned information in the conveyancer signature and identity columns can involve conveyancer as someone who knows and is even considered an intellectual actor in violating the law.

Thus, without comprehensive consideration, the inclusion of signature columns and conveyancer identities can endanger the legal standing of conveyancer as public officials who have worked honestly and professionally. Therefore, the legal consequences arising from the inclusion of a signature column and conveyancer identity contradict the original purpose of the signature column and identity of the conveyancer. Therefore, the SSPD BPHTB form needs some improvements.

\section{Conclusion}

Based on three legal essences which consist of certainty, benefit and justice. Hence, the essence of the policy of the inclusion of conveyancer signature and identity columns on the SSPD BPHTB form in Lombok Island is (1) based on legal certainty that the inclusion of conveyancer signature and identity columns is intended to provide certainty about the conveyancer location and identity that manages the transfer of land rights and provide data certainty for the Regional Government on the profit sharing of tax revenues between the Central Government and the Regional Government. In addition, the absence of conveyancer signature and identity columns on the SSPD BPHTB form provides certainty in the implementation of the self-assessment system in BPHTB collection; (2) based on the benefit that the policy on the inclusion of the conveyancer signature and identity columns can provide benefits to the Regional Revenue Agency, but has a negative impact on the conveyancer. In addition, the absence of conveyancer signature and identity columns does not have a direct consequence, but the benefits of not including the signature and identity columns cannot be eliminated because it is part of the system used by the Regional Revenue Agency in BPHTB collection; (3) based on justice, the inclusion of the conveyancer signature and identity columns does not reflect the principle of justice. The SSPD BPHTB form is basically intended for taxpayers to calculate BPHTB values and as proof of BPHTB payment. Thus, everything related to the form becomes a liability and obligation of the taxpayer. Thus, putting other obligations in the form is a mistake or injustice. 
The legal basis for the inclusion of the conveyancer signature and identity columns on the SSPD BPHTB form can be found in the laws and regulations. Law No. 28 of 2009 gives authority to the regional government to carry out BPHTB collection which is reinforced through the Director General of Taxes Circular No. PEM-01/PJ.09/2010. The authority covers all matters relating to the BPHTB collection. It includes the policy for the inclusion of the conveyancer signature and identity columns on the SSPD BPHTB form. The West Lombok Regency Government and Central Lombok Regency have stipulated Regional Regulation No. 1 of 2011 concerning BPHTB and Regional Regulation No. 14 of 2010 concerning Regional Tax as a legal basis for taking policies in BPHTB collection. The Regional Regulation states that BPHTB payments are made by taxpayers using the SSPD and further provisions regarding the form, content, size, procedure for payment and delivery of SSPD are stipulated by Regent Regulation. However, the provisions regarding the form, content, size, procedure for payment and delivery of the SSPD are not regulated through Regent Regulation. Hence, in this case, there is a legal vacuum to include or not to include the conveyancer signature and identity columns on the SSPD BPHTB form.

The policy for the inclusion of the conveyancer signature and identity columns on the SSPD BPHTB form has a legal consequence on the conveyancer. Legal consequences include that the conveyancer signature and identity column on the SSPD BPHTB form can create liability and sanction.

\section{References}

\section{Books}

Bawazier, F. (2018). Reformasi Pajak di Indonesia Tax Reform In Indonesia. Jurnal Legislasi Indonesia, 8(1), 1-28.

Ismail, T. (2005). Pengaturan Pajak Daerah di Indonesia, Departemen Keuangan Republik Indonesia Badan Pengkajian Ekonomi Keuangan dan Kerjasama Internasional Pusat Evaluasi Pajak dan Retribusi Daerah. PT Yellow Mediatama, Jakarta.

Marzuki, M. (2017). Penelitian Hukum: Edisi Revisi. Jakarta: Prenada Media.

Marzuki, P. M. (2008). Pengantar Ilmu Hukum, Jakarta: Kencana.

Mertokusumo, S. (2010). Mengenal Hukum: Sebuah Pengantar. Yogyakarta: Universitas Atma Jaya.

Mustofa. (2014). Tuntunan Pembuatan Akta-Akta PPAT. Yogyakarta: KaryaMedia.

Shidarta, D. D. (2006). Apa dan Bagaimana Filsafat Hukum Indonesia. Jakarta: Gramedia.

Soeroso, R. (2009). Pengantar Ilmu Hukum, Cet. Kesebelas, Jakarta: Sinar Grafika.

\section{Interview}

Abdul Khalid P., the result of interview with notary/ conveyancer official, Jalan Pariwisata, Bale Pelangi Sandik Batulayar Housing, February 18, 2019.

Dwiratna Kurniasari, the result of interview with notary/ conveyancer official, Jalan Pariwisata Gunung Sari, February 19, 2019.

Djuju Hendro, the result of interview with conveyancer official, Gerung, February 22, 2019. 
Eti Susanti, the result of interview with notary/ conveyancer official, Jalan Raya Senggigi Km 4 Senteluk Batulayar, February 18, 2019.

Fitri Susanti, the result of interview with notary/ conveyancer official, Jalan Soekarno Hatta Gerung, February 22, 2019.

Haerun Inayah, the result of interview with conveyancer official, Jalan Raya Jatisela No. 1 Sesela Gunung Sari, February 22, 2019.

Halim Nata Atmadja, the result of interview with notary/ conveyancer official, Jalan Jendral Sudirman No. 88a, Leneng Praya, February 17, 2019.

I Made Budi Priyatnadi, the result of interview with notary/ conveyancer official, Jalan TGH Lopan No. 19 Labu Api, February 19, 2019.

Lalu Abdurrahman, the result of interview with notary/ conveyancer official, Jalan S. Parman No. 4 Praya, February 17, 2019.

Lalu Jayaprana, results of the interview with the Head of Land and Building Tax and BPHTB, Financial Revenue Agency of Central Lombok Regency, February 12, 2019.

Lalu Mulyadi, the result of interview with notary/ conveyancer official, Jalan TGH. Ibrahim Khalidy, Bengkel, February 13, 2019.

Nining Herlina, the result of interview with notary/ conveyancer official, Jalan HL Anggrat No. 10 North Gerung, February 15, 2019.

Nani Suryani, the result of interview with notary/ conveyancer official, Jalan TGH Saleh Hambali, Bengkel, February 13, 2019.

Muhammad Shaleh Hambali, the result of interview with notary/ conveyancer official, Jalan Raya Senggigi No. 27 Meninting Batulayar, February 19, 2019.

Samsaimun, the result of interview with notary/ conveyancer official, Jalan Selaparang Gerung Selatan, February 15, 2019.

Saharjo, the result of interview with notary/ conveyancer official, Jalan Anyelir No. 36 Prapen Praya, February 12, 2019.

Saipul Rahman, the result of interview with notary/ conveyancer official, Jalan Raya Senggigi Meninting Batulayar, February 18, 2019.

Sayaman Harahap, the result of interview with notary/ conveyancer official, Jalan Pariwisata Batu Layar, February 22, 2019.

Wira Kurniawan, results of the interview with the Head of Land and Building Tax and BPHTB, Financial Revenue Agency of West Lombok Regency, February 11, 2019.

\section{Legislation}

Indonesia, Law No. 20 of 2000 concerning Amendments to Law No. 21 of 1977 concerning the Fees for 
Acquisition of Land and Building Rights, State Gazette of 2000 No. 130, Supplement to State Gazette No. 3988.

Indonesia, Law No. 28 of 2009 concerning Regional Taxes and Regional Levies, State Gazette of 2009 No.130, Supplement to State Gazette No. 5049.

Indonesia, Regional Regulation No. 14 of 2010 concerning Regional Taxes, Supplement to Regional Gazette of Central Lombok Regency No. 14.

Indonesia, Regional Regulation No. 1 of 2011 concerning the Fees for Land and Building Rights, Supplement to Regional Gazette of West Lombok Regency No. 98.

Indonesia, Circular Letter of Director General of Tax Number Pem-01/PJ.09/2010 concerning Transfer of Management of Fees for Land and Building Rights.

\section{Internet}

Kamus Besar Bahasa Indonesia, https://kbbi.kemdikbud.go.id/entri/esensi, diakses pada 15 Maret 2019.

Peraturan Pajak,Lampiran Surat Setoran BPHTB, lihat di

https://pajaksite.files.wordpress.com/2018/02/kep-269-pj-2001.pdf, diakses pada 2 April 2019.

\section{Copyrights}

Copyright for this article is retained by the author(s), with first publication rights granted to the journal. This is an open-access article distributed under the terms and conditions of the Creative Commons Attribution license (http://creativecommons.org/licenses/by/4.0/). 